University of Nebraska - Lincoln

DigitalCommons@University of Nebraska - Lincoln

Faculty Papers and Publications in Animal

Science

Animal Science Department

4-1-1983

\title{
SIMULATION OF HETEROSIS EFFECTS ON COSTS OF PORK PRODUCTION
}

\author{
G. L. Bennett \\ University of Nebraska-Lincoln, gary.bennett@ars.usda.gov \\ M. W. Tess \\ University of Nebraska-Lincoln \\ G. E. Dickerson \\ University of Nebraska-Lincoln \\ R. K. Johnson \\ University of Nebraska-Lincoln, rjohnson5@unl.edu
}

Follow this and additional works at: https://digitalcommons.unl.edu/animalscifacpub

Part of the Animal Sciences Commons

Bennett, G. L.; Tess, M. W.; Dickerson, G. E.; and Johnson, R. K., "SIMULATION OF HETEROSIS EFFECTS

ON COSTS OF PORK PRODUCTION" (1983). Faculty Papers and Publications in Animal Science. 32.

https://digitalcommons.unl.edu/animalscifacpub/32

This Article is brought to you for free and open access by the Animal Science Department at DigitalCommons@University of Nebraska - Lincoln. It has been accepted for inclusion in Faculty Papers and Publications in Animal Science by an authorized administrator of DigitalCommons@University of Nebraska - Lincoln. 


\title{
SIMULATION OF HETEROSIS EFFECTS ON COSTS OF PORK PRODUCTION ${ }^{1}$
}

\author{
G. L. Bennett ${ }^{2}$, M. W. Tess ${ }^{3}$, G. E. Dickerson ${ }^{4}$ and R. K. Johnson ${ }^{5}$ \\ University of Nebraska \\ and \\ US Department of Agriculture, Lincoln, NE 68583-0908
}

\section{Summary}

Individual plus maternal heterotic effects on swine production were simulated with a bioeconomic model by changing performance levels of eight traits: $-8 \mathrm{~d}$ in age at puberty, $+3 \%$ in conception rate, +.94 in pigs born/litter, +.035 $\mathrm{kg}$ in pig birth weight, $+2.05 \mathrm{Mcal} \cdot \mathrm{sow}^{-1} \cdot \mathrm{d}^{-1}$ in maximum milk output, $+8 \%$ in preweaning survival, $+10.8 \%$ in protein growth rate and $+17.3 \%$ in fat growth rate. Associated heterosis simulated for other traits, such as weaning weights and postweaning gain/feed, was similar to experimental results. Effects of heterosis on biological (feed Mcal $/ \mathrm{kg}$ ) and economic $(\$ / \mathrm{kg}$ ) costs were evaluated by simulating two- and three-breed crosses and purebred production. Pig heterosis reduced $\$ / \mathrm{kg}$ lean or $\$ / \mathrm{kg}$ live weight by $4 \%$ for marketing at $100 \mathrm{~kg}$, and by $6 \%$ for $\$ / \mathrm{kg}$ of lean and $8 \%$ for $\$ / \mathrm{kg}$ of live weight for marketing at average 185-d weight. Sow heterosis reduced $\$ / \mathrm{kg}$ lean or $\$ / \mathrm{kg}$ live weight about $4 \%$. Pig heterosis reduced feed $\mathrm{Mcal} / \mathrm{kg}$ by only $1 \%$ and $\mathrm{Mcal} / \mathrm{kg}$ live weight by $3 \%$, and both were reduced only $1 \%$ by maternal heterosis. Traits that reduced litter costs $/ \mathrm{kg}$ of

\footnotetext{
${ }^{1}$ Published as Paper No. 6756, Journal Ser., Nebraska Agr. Exp. Sta., Lincoln.

${ }^{2}$ Postdoctoral Research Associate, Dept. of Anim. Sci., Univ, of Nebraska, Lincoln. Supported by Cooperative Agreement No. 3090-20372-013A or ARS, USDA, and Univ. of Nebraska. Present address: Ruakura Anim. Res. Sta., Ministry of Agr. and Fisheries, Hamilton, New Zealand.

${ }^{3}$ Graduate Assistant, Dept. of Anim. Sci, Univ, of Nebraska, Lincoln. Present address: Dept. of Anim. Sci., North Carolina State Univ., Raleigh 27650.

${ }^{4}$ Research Geneticist, Roman L. Hruska US Meat Animal Research Center, ARS, USDA, 225 Marvel Baker Hall, Univ. of Nebraska, Lincoln 68583-0908.

${ }^{3}$ Professor, Dept. of Anim. Sci., Univ. of Nebraska, Lincoln 68583-0908.
}

output by increasing output/litter were responsible for most effects of heterosis on $\$ / \mathrm{kg}$. However, heterosis in growth rate was important for feed $\mathrm{Mcal} / \mathrm{kg}$ of lean marketed at $100 \mathrm{~kg}$, and for feed $\mathrm{Mcal} / \mathrm{kg}$ of live weight marketed at either $100 \mathrm{~kg}$ or at $185 \mathrm{-d}$ weight. Nonfeed costs $/ \mathrm{kg}$ lean or live weight marketed at $100 \mathrm{~kg}$ were reduced more than feed costs by pig heterosis $(-5$ or -6 vs -2 or $-3 \%)$ and by sow heterosis $(-8$ vs -1 or $-2 \%$ ). Effects of pig heterosis on nonfeed costs were increased to -12 or $-14 \%$ by marketing at mean $185-\mathrm{d}$ weight. Percentage reductions in total costs from heterosis were about one-third as large as corresponding increases in output/litter at market age.

(Key Words: Swine, Simulation, Heterosis, Crossbreeding, System Efficiency.)

\section{Introduction}

Heterosis is an important genetic element in swine production and largely accounts for the fact that most market pigs produced in the United States are crossbreds. Heterosis and breed effects together are the primary genetic components of efficiency in swine crossbreeding systems.

Many investigators have estimated heterosis for traits of swine. Sellier (1976) has reviewed European crossbreeding experiments and Johnson (1981) has reviewed comparable recent experiments in the United States. Heterosis effects have been important for litter size, litter weight and growth rate, but not for carcass traits. The components of heterosis for litter traits are usually assumed to be number at birth, viability and mothering ability.

The effect of heterosis on the efficiency of pork production is often expressed as increased litter weight/sow. Because costs of pork production associated with the sow are only about 
$40 \%$ of all costs (Tess et al., 1983a), the effect of heterosis on efficiency is described better by the reduction in total cost of production.

One purpose of this paper is to better understand observed individual and maternal heterosis by simulating heterosis changes in a relatively small number of underlying biological traits with the aid of a pork production model (Tess et al., 1983a). Another purpose is to evaluate the effect of heterosis on efficiency of pork production and the contribution of each basic genetic component to the total effect of heterosis.

\section{Materials and Methods}

One method of estimating individual heterosis is to compare crossbred offspring to purebred offspring with general combining ability and maternal environment equalized. A similar method of estimating maternal heterosis is to compare crossbred offspring raised by crossbred dams with those raised by purebred dams, when the comparison is balanced for general combining abilities of both offspring and dams. These methods were simulated with a swine production model described by Tess et al. (1983a). Features of this model that are especially relevant to this study are: 1) feed for mainte- nance and growth is dependent on metabolic lean mass maintained and on amount of protein and fat deposited; 2) sow milk energy production interacts with litter size and pig genotype on a daily basis to determine pig survival, growth and composition until pigs take creep feed and 3) genetic performance levels are specified separately for sows and their progency.

The simulation of crossbreeding experiments used hypothetical breeds that were alike in general combining and maternal abilities, but which expressed heterosis when crossed. Heterosis simulated for any of the basic traits was the same in both the individual and maternal estimation experiments. Crossbred pigs raised by purebred sows had exactly the same genotype as crossbred pigs raised by crossbred sows.

The eight genetic components manipulated to simulate heterosis with the simulation model were birth weight, protein growth rate, fat growth rate, preweaning viability, age at puberty, conception rate, litter size as a trait of the dam and milk energy output. Heterosis levels simulated for the eight genetic components (table 1) were based on results from recent crossbreeding experiments conducted at Iowa State University (Schneider, 1978) and at Oklahoma State University (Young et al.,

TABLE 1. SIMULATED PERFORMANCE OF PUREBRED AND CROSSBRED PIGS FROM PUREBRED SOWS, AND ESTIMATED PIG HETEROSIS EFFECTS

\begin{tabular}{|c|c|c|c|c|c|}
\hline \multirow{3}{*}{ Trait } & \multicolumn{2}{|c|}{ Simulated performance } & \multicolumn{3}{|c|}{ Heterosis } \\
\hline & \multirow{2}{*}{$\frac{\text { Crossbred }}{8.96^{\mathrm{b}}}$} & \multirow{2}{*}{$\frac{\text { Purebred }}{8.96^{\mathrm{b}}}$} & \multirow{2}{*}{$\frac{\text { Simulated }}{.00}$} & \multicolumn{2}{|c|}{ Experimentala } \\
\hline & & & & .04 & \pm .19 \\
\hline Litter size at $21 \mathrm{~d}$ & $6.83^{\mathrm{b}}$ & $6.37^{b}$ & .46 & .44 & $\pm \quad .17$ \\
\hline Litter size at weaning & $6.83^{b}$ & $6.37^{b}$ & .46 & .51 & $\pm .17^{c}$ \\
\hline Pig wt at birth, $\mathrm{kg}$ & $1.37 \mathrm{~b}$ & $1.34^{b}$ & .03 & .03 & $\pm .01^{\mathrm{c}}$ \\
\hline Pig wt at $21 \mathrm{~d}, \mathrm{~kg}$ & $5.05^{b}$ & $4.85^{b}$ & .20 & .26 & \pm .07 \\
\hline Pig wt at weaning, $\mathrm{kg}$ & $13.1^{\mathrm{b}}$ & $12.1^{\mathrm{b}}$ & 1.0 & .9 & .2 \\
\hline Litter wt at birth, kg & $12.3^{b}$ & $12.0^{b}$ & .3 & .4 & \pm .2 \\
\hline Litter wt at $21 \mathrm{~d}, \mathrm{~kg}$ & $34.6^{b}$ & $30.9^{b}$ & 3.7 & 3.9 & \pm .9 \\
\hline Litter wt at weaning, $\mathrm{kg}$ & $90^{\mathrm{b}}$ & $77^{b}$ & 13 & 12 & \pm 3 \\
\hline Daily gain postweaning, $\mathrm{kg} / \mathrm{d}$ & $.709 \mathrm{~d}$ & $.648^{d}$ & .061 & .062 & \pm .005 \\
\hline Days to $100 \mathrm{~kg}$ & $171.6^{\mathrm{d}}$ & $184.9^{d}$ & -13.3 & -13.7 & $\pm 1.0^{\mathrm{c}}$ \\
\hline Gain/feed & $.3250^{\mathrm{d}}$ & $.3173^{d}$ & .0077 & .0073 & \pm .0030 \\
\hline Carcass backfat, cm & $2.83^{d}$ & $2.80^{\mathrm{d}}$ & .03 & .035 & $.03^{\mathrm{c}}$ \\
\hline$\%$ fate & 34.47 & 34.21 & .26 & .30 & .26 \\
\hline
\end{tabular}

\footnotetext{
${ }^{a}$ Average values from Iowa and Oklahoma experiments, with pooled standard errors. See text.

${ }^{b}$ Unweighted average of litters from first- and second-parity dams.

${ }^{c}$ Values used to determine simulated genetic values.

d Unweighted average of gilts and barrows from first- and second-parity dams.

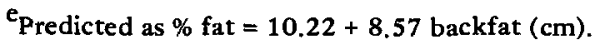


1976a,b; Johnson et al., 1978; Hutchens, 1980).

Because of the structure of the pig model, it was necessary to simulate heterosis of basic genetic components in a specific sequential manner, using the predetermined average experimental values for each of the eight components from the Iowa and Oklahoma experiments. First, purebred values that approximated average literature purebred values were used as a base. Then the experiments to estimate cost reduction from individual heterosis were simulated by increasing crossbred progeny genotypes for birth weight, fat growth rate and protein growth rate, so that average experimental values of individual heterosis for birth weight, days to $100 \mathrm{~kg}$ live weight and backfat thickness at $100 \mathrm{~kg}$ were closely approximated. The simulation computed percentage empty body fat, which was converted to backfat at $100 \mathrm{~kg}$ by the equation: backfat $(\mathrm{cm})$ at $100 \mathrm{~kg}$ $=.35+.07 \times$ percentage fat at $100 \mathrm{~kg}$ (Cleveland, 1981). The simulation was then rerun after increasing preweaning viability of crossbred progeny so that simulated heterosis in number of pigs weaned closely approximated the experimental value. Number of pigs weaned rather than pig weaning weight was approximated because of its greater economic importance.

Maternal heterosis was then simulated using the previously determined heterosis values for preweaning viability, birth weight, fat growth rate and protein growth rate of both pigs and crossbred sows. Also, performance of crossbred sows for age at puberty, conception rate and number at birth was set at approximately the experimental values for those traits. In the simulation model, the only effect of sow performance on pig survival was through milk energy effects on the pigs' fat reserves. The milk energy output of the crossbred sow was increased to approximate demands from experimental maternal heterosis for number weaned. However, the potential level of milk energy production assumed initially for purebred sows was too high for a further increase in crossbred sows to produce the experimental increase in number weaned. Therefore, maternal heterosis values were resimulated, starting with lower potential purebred milk energy outputs, until experimental maternal heterosis for number weaned was approximated.

Effects of heterosis for individual performance on efficiency were evaluated by comparing crossbred with purebred market pigs raised by purebred sows. Effects of heterosis in maternal ability were evaluated by comparing crossbred and purebred sows both raising crossbred pigs. Heterosis for maternal ability includes maternal heterosis effects on progeny performance, reproductive heterosis of sows and individual heterosis for size and composition of the sow.

The simulations determining heterosis effects on efficiency were repeated after individually setting heterosis for age at puberty, conception rate, number born, milk energy, preweaning viability, growth rate or backfat to zero. Deviations of these estimates of heterosis from the base levels for all heterosis effects on efficiency then were used to estimate the relative importance of heterosis (individual and maternal) for each trait.

Four measures of production efficiency were calculated. Biological efficiency was computed as metabolizable feed energy (ME) in $\mathrm{Mcal} / \mathrm{kg}$ of carcass lean or of empty body weight. Economic efficiency was computed as cost in $\$ / 100 \mathrm{~kg}$ of carcass lean or of live weight. Pigs were marketed at $100 \mathrm{~kg}$ live weight or at the average weight at $185 \mathrm{~d}$ of age. These measures of efficiency and their impact on breeding goals have been discusssed by Tess et al. $(1983 \mathrm{~b}, \mathrm{c})$.

Simulations were based upon a management system found to be nearly optimum economically by Tess et al. (1983a), one which included a maximum of three parities/sow and weaning at 7 wk. Creep feed was offered from 3 wk of age to weaning. Replacement gilts were assumed to be purchased at a cost of $\$ 100$ or $1,200 \mathrm{Mcal}$ $M E / 100 \mathrm{~kg}$ gilt for economic or biological efficiency, respectively, regardless of breeding. Typical midwestern production costs were used (Tess et al., 1983a). Feed prices were based on $\$ 9.84 / 100 \mathrm{~kg}$ of corn.

\section{Results}

Heterosis Effects. on Performance. Results from simulating performance of crossbred and purebred offspring from purebred females are shown in table 1 in comparison with simulated and average experimental values of heterosis. Potential crossbred progeny performance was increased to approximate experimental heterosis levels only for the four component traits: preweaning viability, birth weight, protein growth rate and fat growth rate. Heterosis for other traits resulted from associations within 
TABLE 2. SIMULATED PERFORMANCE OF PUREBRED AND CROSSBRED SOWS WITH CROSSBRED PIGS, AND ESTIMATED SOW HETEROSIS EFFECTS

\begin{tabular}{|c|c|c|c|c|c|}
\hline \multirow{3}{*}{$\frac{\text { Trait }}{\text { Age at puberty, } d}$} & \multicolumn{2}{|c|}{ Simulated performance } & \multicolumn{3}{|c|}{ Heterosis } \\
\hline & \multirow{2}{*}{$\frac{\text { Crossbred }}{200}$} & \multirow{2}{*}{ Purebred } & \multirow{2}{*}{$\frac{\text { Simulated }}{-8}$} & \multicolumn{2}{|c|}{ Experimentala } \\
\hline & & & & -7.9 & $\pm 2.0^{\mathrm{b}}$ \\
\hline Conception rate, $\%$ & 75.0 & 72.0 & 3.0 & $3.0^{\mathrm{b}}$ & \\
\hline Litter size at birth & $9.90^{\mathrm{c}}$ & $8.96^{\mathrm{c}}$ & .94 & .93 & $\pm .24^{b}$ \\
\hline Litter size at $21 \mathrm{~d}$ & $7.73^{\mathrm{c}}$ & $6.83^{\mathrm{c}}$ & .90 & .94 & \pm .22 \\
\hline Litter size at weaning & $7.73^{\mathrm{c}}$ & $6.83^{\mathrm{c}}$ & .90 & .88 & $\pm .21^{b}$ \\
\hline Pig wt at birth, $\mathrm{kg}$ & $1.34^{\mathrm{c}}$ & $1.37 \mathrm{c}$ & -.03 & -.01 & \pm .014 \\
\hline Pig wt at $21 \mathrm{~d}, \mathrm{~kg}$ & $5.19 \mathrm{c}$ & $5.05^{\mathrm{C}}$ & .14 & .16 & \pm .06 \\
\hline Pig wt at weaning, $\mathrm{kg}$ & $13.24^{\mathrm{c}}$ & $13.11^{\mathrm{c}}$ & .13 & .3 & \pm .27 \\
\hline Litter wt at birth, kg & $13.4^{\mathrm{C}}$ & $12.3^{\mathrm{c}}$ & 1.1 & 1.3 & \pm .3 \\
\hline Litter wt at $21 \mathrm{~d}, \mathrm{~kg}$ & $40.2^{\mathrm{c}}$ & $34.6^{\mathrm{C}}$ & 5.6 & 6.4 & \pm 1.2 \\
\hline Litter wt at weaning, $\mathrm{kg}$ & 102 & 90 & 12 & 14 & \pm 3 \\
\hline Daily gain postweaning, $\mathrm{kg} / \mathrm{d}$ & $.709^{d}$ & $.709 \mathrm{~d}$ & .000 & -.005 & \pm .006 \\
\hline Days to $100 \mathrm{~kg}$ & $171.4^{\mathrm{d}}$ & $171.6^{\mathrm{d}}$ & -.2 & .4 & \pm 1.0 \\
\hline Gain/feed & $.3245^{\mathrm{d}}$ & $.3250^{d}$ & -.0005 & .000 & \pm .003 \\
\hline Carcass backfat, $\mathrm{cm}$ & $2.84^{\mathrm{d}}$ & $2.83^{\mathrm{d}}$ & .01 & .035 & \pm .03 \\
\hline$\$$ fat $^{\mathrm{e}}$ & 34.56 & 34.47 & .09 & .30 & \pm .26 \\
\hline
\end{tabular}

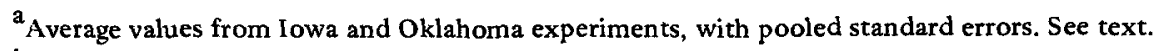

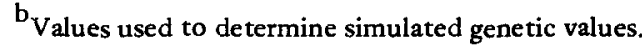

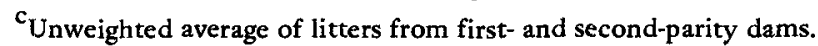

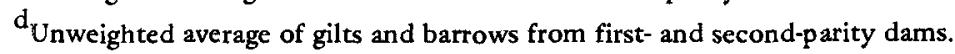

$\mathrm{e}_{\text {Predicted as } \% \text { fat }}=10.22+8.57$ backfat $(\mathrm{cm})$.

the model with these four "driving" genetic components, but were also similar to experimental estimates.

Close agreement between simulated and experimental heterosis was expected for traits such as litter size at $\mathbf{2 1} \mathbf{d}$ and postweaning daily gain that were closely related to the four "driving" experimental values. Other simulated traits, such as gain/feed, pig weights and litter weights at $21 \mathrm{~d}$ were not as obviously related, and their close agreement with experimental heterosis supports the proportional effect of heterosis on all stages of growth that was assumed in the model. The close agreement of simulated and experimental heterosis for gain/feed was predicted from the increases in fat and protein growth with no heterosis effect on either maintenance energy/unit metabolic size or above-maintenance energy costs of fat and protein deposition. Thus, results gave no suggestion that heterosis affected unit energy costs for maintenance or tissue deposition.

Results of simulating crossbred progeny from purebred and crossbred females are shown in table 2, in comparison with the experimental values for heterosis. Preweaning viability, birth weight, fat growth rate and protein growth rate were increased in the progeny and in the crossbred sows by the same amount as determined for crossbred pigs from purebred sows in the previous simulations. Age at puberty, conception rate, litter size at birth and maximum daily milk energy production were then changed iteratively, until the first three traits and litter size weaned approached the experimental heterosis values. Simulated increased milk energy from crossbred sows improved pig viability because viability of crossbred pigs from purebred sows was reduced by their limited milk production.

Sow heterosis for milk energy also increased preweaning pig and litter weights within one standard error of experimental values. The increased milk energy from crossbred sows allowed their pigs to express only slightly more of their potential fat growth.

A summary of the eight changes in genetic components used to simulate experimental heterosis differences among the purebred and the two- and three-breed crosses is presented in table 3. Changes in protein and fat growth rate were measured at $5 \mathrm{mo}$ of age and thus appear 
TABLE 3. SIMULATED TOTAL HETEROSIS IN BASIC GENETIC COMPONENT TRAITS

\begin{tabular}{lcc}
\hline & \multicolumn{2}{c}{ Heterosis } \\
\cline { 2 - 3 } Trait & Actual & $\%$ \\
\hline Age at puberty, d & -8 & -3.8 \\
Conception rate, \% & 3.0 & 4.2 \\
Litter size at birth & .94 & 10.7 \\
Pig birth wt, kg & .035 & 2.5 \\
Preweaning survival, \% & 8.0 & 11.11 \\
Maximum milk energy, Mcal/d & 2.05 & 25 \\
Protein growth rate, kg/d & $.0106^{\mathrm{a}}$ & 10.75 \\
Fat growth rate, kg/d & $.0475^{\mathrm{a}}$ & 17.32 \\
& & \\
\hline
\end{tabular}

${ }^{a}$ For gilts at $154 \mathrm{~d}$ of age.

to be larger in percentage than when expressed at a constant weight or in terms of age at a fixed weight.

The $25 \%$ increase in maximum milk energy (table 3 ) is higher than most estimates of heterosis for any quantitative trait. To examine sensitivity to heterosis effects on milk production, levels from 5 to $25 \%$ were tried. Simulated maternal heterosis for litter size and pig weight at $21 \mathrm{~d}$ for these levels of milk production are shown in table 4. Average experimental heterosis for both traits was consistent with $25 \%$ heterosis for maximum milk energy. The simulation model allows for differences in the height of the milk-energy curve, but not in its shape. Changes in shape as well as maximum production could cause similar results at a much lower maximum milk production. Most deaths occur early in the lactation so that early milk energy affects survival much more than maximum milk energy. Illustrated in figure 1 are the crossbred and purebred milk energy levels that were simulated as well as an alternate crossbred curve that would give similar results. The alternate crossbred curve illustrates $25 \%$ heterosis for first-day milk energy, but only $10 \%$ heterosis for maximum milk energy.

Heterosis Effects on Efficiency. Several measures of pork production efficiency for purebreds and for two- and three-breed crosses are presented in table $\mathbf{5}$, for marketing at $\mathbf{1 0 0}$ $\mathrm{kg}$ live weight (WT), and for marketing at the mean weight reached at $185 \mathrm{~d}$ of age (AGE). Increased efficiency of two-breed cross over purebred production resulted from individual heterosis in market pigs and will be referred to as heterosis for individual performance. Increased efficiency of three-breed over the two-breed cross resulted from individual heterosis in sows and maternal heterosis effects on market pigs and will be referred to as heterosis for maternal performance.

Heterosis for individual and maternal performance each reduced production costs $(\$ / \mathrm{kg}$ carcass lean or live weight) by $4 \%$ when pigs were marketed at $100 \mathrm{~kg}$. When marketing was at mean 185-d weight, the effects of heterosis for individual performance increased relative to maternal heterosis because this marketing policy allowed heterosis for growth rate to increase weight marketed per litter. The increased litter weight reduced the sow and litter costs per unit of weight marketed. Costs were not reduced by individual heterosis as much for carcass lean as for live weight $(-6$ vs $-8 \%)$ because crossbred pigs were slightly fatter. However, the effect of maternal heterosis was the same for $\$ / \mathrm{kg}$ of lean or live weight $(-4 \%)$.

Total effects of heterosis on feed energy $/ \mathrm{kg}$ of either lean or live weight to $100 \mathrm{~kg}$ market (WT) weight were only about $-4 \%$ compared with -8 to $-9 \%$ for total cost $/ 100 \mathrm{~kg}$. Individual heterosis accounted for $-3 \%$ and maternal heterosis for $-1 \%$ reductions in feed $/ \mathrm{kg}$, but for -4.0 and $-4.5 \%$ reductions in total cost $/ 100 \mathrm{~kg}$. Marketing at mean $185-\mathrm{d}$ weight (AGE) decreased the effects of individual heterosis on feed $/ \mathrm{kg}$ of lean meat production to $-1 \%$ because daily lean gain decreased and daily fat gain increased in the last part of the

TABLE 4. SIMULATED MATERNAL HETEROSIS FOR LITTER SIZE AND PIG WEIGHT AT 21 DAYS FOR DIFFERENT LEVELS OF HETEROSIS FOR MILK-ENERGY PRODUCTION

\begin{tabular}{|c|c|c|c|c|c|c|}
\hline \multirow[b]{2}{*}{ Trait } & \multicolumn{5}{|c|}{$\%$ heterosis in milk energy } & \multirow[b]{2}{*}{ Experimental } \\
\hline & 5 & 10 & 15 & 20 & 25 & \\
\hline Litter size at $21 \mathrm{~d}$ & .48 & .63 & .74 & .83 & .90 & $.94 \pm .22$ \\
\hline Pig wt at $21 \mathrm{~d}, \mathrm{~kg}$ & -.04 & .00 & .04 & .09 & .14 & $.16 \pm .06$ \\
\hline
\end{tabular}




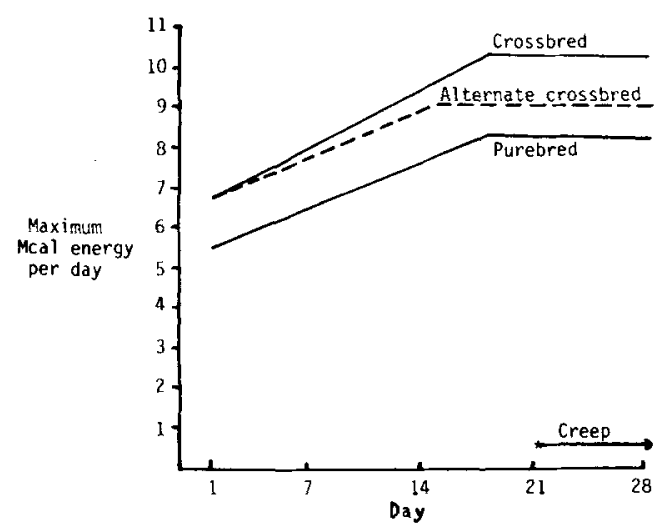

Figure 1. Purebred, crossbred and an alternate crossbred sow lactation milk energy curve, in which heterosis is $25 \%$ for initial but only $10 \%$ for peak potential production.

feeding period. The smaller effect of heterosis for maternal performance on feed $/ \mathrm{kg}$ than on total costs $/ 100 \mathrm{~kg}(-1$ vs $-4 \%)$ under either WT or AGE marketing reflects the relatively small proportion of total feed energy and large proportion of total nonfeed costs required by sows.

Trait Effects on Heterosis for Efficiency. Contributions of individual traits to the total effect of heterosis on efficiency were assessed by individually setting heterosis effects for age at puberty, conception rate, litter size at birth, pig birth weight, preweaning survival and maximum milk energy to zero. Fat and protein growth rate were adjusted so that either heterosis for days to $100 \mathrm{~kg}$ was zero with no change in backfat, or heterosis for backfat was set to zero with no change in days to $100 \mathrm{~kg}$. Then purebreds and two- and three-breed crosses were simulated, and effects of heterosis for individual and maternal performance were recalculated. The difference between the full heterosis and the recalculated values provided an estimate for the effects on efficiency of heterosis for individual and maternal performance in each of the traits. When the sums of these values are not equal to the combined heterosis effect, nonlinearity or interaction is indicated.

Individual contributions of traits to effects of heterosis for individual and maternal performance on efficiency are presented in table 6 . Sums of separate contributions for heterosis of individual performance were only 1 to $5 \%$ greater than the combined contributions of all traits, except for $\mathrm{Mcal} / \mathrm{kg}$ lean. For $\mathrm{Mcal} / \mathrm{kg}$ lean, the sum exceeded the combined effects by $10 \%$ at constant weight and by $30 \%$ at constant age marketing, because the heterotic increase in fat deposition became increasingly detrimental to lean yield at the heavier market weights.

Effects on economic efficiency of heterosis for individual performance resulted primarily from increased preweaning viability when marketed at $100 \mathrm{~kg}$, but also from increased growth rate when marketed at an average age of $185 \mathrm{~d}$. Heterosis increased backfat, which increased cost of carcass lean production, but did not increase cost of live weight production.

Effects of heterosis for individual performance on biological efficiency resulted from increased preweaning viability and growth rate when marketed at $100 \mathrm{~kg}$ live weight. When marketed at mean 185-d weight, heterotic increase in growth rate had only a small effect on biological efficiency of lean production, because lean content decreased and feed consumption increased past $100 \mathrm{~kg}$. Heterosis for backfat de-

TABLE 5. SIMULATED EFFECTS OF HETEROSIS ON FOUR MEASURES OF EFFICIENCY WHEN PIGS ARE MARKETED AT 100 KG LIVE WEIGHT (WT) OR AT MEAN 185-D WEIGHT (AGE)

\begin{tabular}{lllcll}
\hline $\begin{array}{l}\text { Market } \\
\text { policy }\end{array}$ & Genetic group & $\$ / 100 \mathrm{~kg}$ lean & $\$ / 100 \mathrm{~kg}$ wt & Mcal/kg lean & Mcal/kg wt \\
\hline WT & Purebred & $191.9(100.0)^{\mathrm{a}}$ & $100.3(100.0)$ & $22.84(100.0)$ & $12.54(100.0)$ \\
& Two-breed cross & $184.7(96.2)$ & $96.0(95.7)$ & $22.25(97.4)$ & $12.15(96.9)$ \\
& Three-breed cross & $176.0(91.7)$ & $91.5(91.2)$ & $21.91(95.9)$ & $11.98(95.5)$ \\
AGE & Purebred & $191.9(100.0)$ & $100.3(100.0)$ & $22.84(100.0)$ & $12.54(100.0)$ \\
& Two-breed cross & $179.8(93.7)$ & $92.0(91.8)$ & $22.66(99.2)$ & $12.20(97.2)$ \\
& Three-breed cross & $171.8(89.5)$ & $\mathbf{8 8 . 0 ( 8 7 . 8 )}$ & $22.34(97.8)$ & $12.03(95.9)$ \\
\hline
\end{tabular}

\footnotetext{
${ }^{\mathbf{a}}$ Percentage in parentheses.
} 
TABLE 6. CONTRIBUTIONS OF INDIVIDUAL TRAITS TO EFFECTS OF HETEROSIS ON EFFICIENCY ${ }^{a}$

\begin{tabular}{|c|c|c|c|c|}
\hline Item & $\$ / 100 \mathrm{~kg}$ lean & $\$ / 100 \mathrm{~kg} \mathrm{wt}$ & Mcal $/ \mathrm{kg}$ lean & Mcal $/ \mathrm{kg}$ wt \\
\hline \multicolumn{5}{|l|}{$\begin{array}{l}\text { Two-breed vs purebred } \\
\text { difference in: }\end{array}$} \\
\hline Birth wt & .08 & .04 & .006 & .004 \\
\hline Preweaning viability & -8.10 & -4.05 & -.459 & -.231 \\
\hline Growth rate & $-.76(-5.70)$ & $-.38(-4.31)$ & $-.373(.029)$ & $-.204(-.161)$ \\
\hline Backfat & 1.21 & .02 & .180 & .021 \\
\hline Sum & $-7.57(-12.50)$ & $-4.37(-8.30)$ & $-.646(-.244)$ & $-.410(-.367)$ \\
\hline Combined & $-7.21(-12.16)$ & $-4.31(-8.24)$ & $-.590(-.188)$ & $-.391(-.348)$ \\
\hline \multicolumn{5}{|l|}{$\begin{array}{l}\text { Three- vs two-breed } \\
\text { difference in: }\end{array}$} \\
\hline Age at puberty & -.86 & -.38 & -.083 & -.041 \\
\hline Conception rate & -1.06 & -.54 & -.075 & -.037 \\
\hline $\begin{array}{l}\text { Litter size } \\
\text { Milk energy }\end{array}$ & $\left.\begin{array}{l}-5.25 \\
-4.93\end{array}\right\}-8.11^{b}$ & $\left.\begin{array}{l}-2.70 \\
-2.54\end{array}\right\}-4.16$ & $\left.\begin{array}{l}-.276 \\
-.195\end{array}\right\}-.359$ & $\left.\begin{array}{r}-.144 \\
-.102\end{array}\right\}-.187$ \\
\hline Preweaning viability & .86 & .34 & .061 & .024 \\
\hline Growth rate & $-.07(.68)$ & $-.27(.20)$ & $.146(.169)$ & $.051(.066)$ \\
\hline Backfat & -.19 & -.13 & -.003 & -.006 \\
\hline Sum & $-11.50(-10.75)$ & $-6.22(-5.75)$ & $-.425(-.402)$ & $-.255(-.240)$ \\
\hline Combined & $-8.72(-7.97)$ & $-4.48(-4.01)$ & $-.343(-.320)$ & $-.177(-.162)$ \\
\hline
\end{tabular}

${ }^{\mathrm{a}}$ For marketing at $100 \mathrm{~kg}$ live weight. Results for marketing at average 185-d weight are shown in parentheses whenever different from $100 \mathrm{~kg}$ marketing.

${ }^{b}$ Numbers following brackets are the combined contribution of milk energy and litter size at birth.

creased both economic and biological efficiency of lean production because crossbred pigs were slightly fatter at market weight.

The sums of separate trait contributions to heterosis for maternal performance (table 6) were 24 to $48 \%$ greater than the combined contributions of all traits, primarily because of interaction between milk energy and litter size at birth. Reducing milk heterosis to zero caused an $8 \%$ decrease in preweaning viability while reducing litter size heterosis to zero did not affect preweaning viability. An additional simulation in which heterosis for both milk energy and litter size at birth were reduced to zero decreased preweaning viability by only $2 \%$. Combining the contributions of maternal heterosis in milk energy and litter size to efficiency reduced the discrepancy between the sum of individual effects and their combined effects on heterosis of maternal performance to the range from $-10 \%$ for $\mathrm{Mcal} / \mathrm{kg}$ lean to +9 to $+16 \%$ for the other three measures of efficiency.

Effects of heterosis for maternal performance on both feed energy and total costs/unit of lean or weight marketed were caused primarily by the combined effects of litter size at birth and milk-energy production. The decreased age at puberty and increased conception rate also reduced feed $/ \mathrm{kg}$ and total cost $/ \mathrm{kg}$. Increased fat in crossbred sows also reduced total costs $/ \mathrm{kg}$ slightly (probably from lower protein and cost of sow feed), but not feed energy $/ \mathrm{kg}$ of lean or live weight.

Heterosis for maternal performance, as measured by the difference between two- and three-way crosses, also depended on the amount of heterosis expressed in the crossbred pigs. The effect of more milk energy in crossbred sows would have been even larger if their crossbred pigs had not expressed heterosis for preweaning viability. At crossbred levels of pig viability, the crossbred sow was not able to improve viability as much as at purebred levels of viability. In other words, the improved environment provided by the crossbred sow had less effect on pigs that were less likely to die.

Increased growth rate of crossbred sows had several small effects on sow maintenance energy and salvage value. Heterosis in growth rate increased sow maintenance feed required more per $\mathrm{kg}$ of lean (.15 to .17) than per $\mathrm{kg}$ of live weight (.05 to .07); it also reduced total sow costs more per $100 \mathrm{~kg}$ of live weight $(-.27)$ than per $\mathrm{kg}$ of lean $(-.07)$ for $100 \mathrm{~kg}$ marketing, but increased total sow costs more per $100 \mathrm{~kg}$ 
of lean (.68) than per $100 \mathrm{~kg}$ of live weight (.20).

Crossbred pigs with high growth rate also interact with the available milk energy. When heterosis for growth rate was increased from zero, maternal heterosis for number weaned increased from .79 to .90 due to reduced mortality from greater milk energy in the three-way cross. This increase in maternal heterosis for number weaned was partially offset by crossbred sows spending more days in the period from $100 \mathrm{~kg}$ to puberty and by higher maintenance energy for the sows. The main effect of individual heterosis for growth on marketing at a constant average age rather than weight was a reduction in litter and sows costs per $\mathrm{kg}$ of output. The effect of heterosis for maternal ability on efficiency when pigs are marketed at a constant average age would have been greater if growth heterosis in their pigs had been zero. After heterosis for growth rate has reduced litter and sow costs in two-way crosses, a smaller proportion of total costs remains to be affected by maternal performance.

Effects on Feed and Nonfeed Costs. Effects of heterosis for individual and maternal performance on economic efficiency were divided between feed and nonfeed costs in table 7 . Heterosis reduced nonfeed costs much more than feed costs/ $\mathrm{kg}$ of either lean or live weight because large sow nonfeed costs were spread over more output. Thus, an increase in feed prices relative to nonfeed prices would reduce the heterosis advantage in total cost $/ \mathrm{kg}$ of product output. This tendency was more pronounced for maternal than for individual performance when marketing was at $100 \mathrm{~kg}$, but was more extreme for individual than for maternal performance when marketing was at 185-d weight, because sow nonfeed costs were spread over more weight/pig marketed.

\section{Discussion}

Heterosis had much greater effects on economic than on biological (feed energy) efficiency. A major effect of increased litter size, viability, milk energy production and weight at a given market age was to spread the large nonfeed costs for the breeding herd and farrowing house over more weight marketed/ litter. Because of the high reproductive rate in swine, the breeding herd consumed only a small portion $(-20 \%)$ of all feed used in the production of pork, so that spreading sow costs over more output has a much smaller effect on biological (feed) than on economic (total cost) efficiency (Tess et al., 1983b).

Live weight/litter at a constant market age increased $20 \%$ in two-way crosses and an additional $16 \%$ in three-way crosses. These increases in litter weight corresponded to decreases of only -8 and $-4 \%$, respectively, in cost $/ \mathrm{kg}$ live weight (table 5). Thus, economic efficiency of live weight production was improved only about one-third as much as total weight/litter. Heterosis for litter weight at constant market age was an even poorer indicator of reduction in total cost $/ \mathrm{kg}$ lean $(-10 \%)$ or in feed energy $/ \mathrm{kg}$ lean $(-2 \%)$ or live weight $(-4 \%)$.

In this model, maternal heterosis for preweaning traits was quite sensitive to assumed levels of milk energy production. Differences in base levels, without heterosis of basic genetic components, would cause apparent differences in heterosis of compound traits such as litter size at weaning. For instance, purebreds with

TABLE 7. EFFECTS OF PIG AND SOW HETEROSIS ON FEED OR NONFEED COSTS AS A PERCENTAGE OF PUREBRED FEED OR NONFEED COSTS

\begin{tabular}{|c|c|c|c|c|}
\hline \multirow[b]{2}{*}{ Heterosis } & \multicolumn{2}{|c|}{$\$ / 100 \mathrm{~kg}$ lean } & \multicolumn{2}{|c|}{$\$ / 100 \mathrm{~kg}$ live wt } \\
\hline & Feed & Nonfeed & Feed & Nonfeed \\
\hline \multicolumn{5}{|l|}{ A. Marketing at $100 \mathrm{~kg}$ live wt } \\
\hline Individual performance & -2.4 & -5.1 & -3.0 & -5.7 \\
\hline Maternal performance & -1.5 & -7.9 & -1.4 & -7.7 \\
\hline \multicolumn{5}{|l|}{ B. Marketing at mean $185-\mathrm{d}$ wt } \\
\hline Individual performance & -1.2 & -11.8 & -.32 & -13.5 \\
\hline Maternal performance & -1.3 & -7.1 & -1.2 & $-7,0$ \\
\hline
\end{tabular}


low litter size at birth and high potential milk energy would show less maternal and more individual heterosis for preweaning traits. Cross-fostering pigs in a crossbreeding experiment might help in predicting performance of specific crosses. Without cross-fostering, effects of litter size at birth, viability and milk are merged in litter size at weaning.

The simulation of heterosis by altering basic genetic components to match predetermined experimental values and observing their effects on other traits is a partial validation of the model described by Tess et al. (1983a). The model reflects the authors' interpretations of experimental results and of biological cause and effect relationships. The success of this model in simulating average results from two crossbreeding experiments does not exclude other models. However, the results do demonstrate ability of the model to predict associated changes in other traits from changes in the basic genetic components.

Tess et al. (1983a) have discussed some weaknesses of the model. In order to simulate maternal heterosis for viability, it was necessary to decrease base purebred level of milk production to the point where crossbred pigs raised by purebred dams were under nutritional stress. It was then possible for heterosis in milk output to relieve the nutritional stress in three-way crosses. This interpretation of maternal heterosis was not based on direct observation of milk energy. Other aspects of maternal ability may contribute to full explanation of maternal heterosis, although they would need to explain increases in both weight and viability of threebreed crossbred pigs.

\section{Literature Cited}

Cleveland, E. R. 1981. Effect of lean growth selection and feed intake on composition and energy utilization in swine and correlated responses in carcass and reproductive traits from lean growth selection in swine. Ph.D. Dissertation. Univ. of Nebraska, Lincoln.

Hutchens, L. K. 1980. Age and weight at puberty of purebred and crossbred gilts involving four breeds and their genetic and phenotypic relationship with growth characteristics. M.S. Thesis. Oklahoma State Univ., Stillwater.

Johnson, R. K. 1981. Crossbreeding in swine: Experimental results. J. Anim. Sci. 52:906.

Johnson, R. K., I. T. Omtvedt and L. E. Walters. 1978. Comparison of productivity and performance for two-breed and three-breed crosses in swine. J. Anim. Sci. 46:69.

Schneider, J. F. 1978. Individual and maternal heterosis estimated from single crosses and backcrosses of swine. Ph.D. Dissertation. Iowa State Univ., Ames.

Sellier, P. 1976. The basis of crossbreeding in pigs; A review. Livestock Prod. Sci. 3:203.

Tess, M. W., G. L. Bennett and G. E. Dickerson. 1983a. Simulation of genetic changes in life cycle efficiency of pork production. I. A. bioeconomic model. J. Anim. Sci. 56:336.

Tess, M. W., G. L. Bennett and G. E. Dickerson. 1983b. Simulation of genetic changes in life cycle efficiency of pork production. II. Effects of components on efficiency. J. Anim. Sci. 56:354.

Tess, M. W., G. L. Bennett and G. E. Dickerson. 1983c. Simulation of genetic changes in life cycle efficiency of pork production. III. Effects of maragement systems and feed prices on importance of genetic components. J. Anim. Sci. 56:369.

Young, L. D., R. K. Johnson and I. T. Omtvedt. 1976a. Reproductive performance of swine bred to produce purebred and two-breed cross litters. J. Anim. Sci. 42:1133.

Young, L. D., R. K. Johnson, I. T. Omtvedt and L. E. Walters. 1976b. Postweaning performance and carcass merit of purebred and two-breed cross pigs. J. Anim. Sci. 42:1124. 